\title{
THE ANTECEDENTS GREEN BRAND EQUITY OF GREEN COSMETICS
}

\author{
Maria Angela Diva V.W. \\ Manajemen, Fakultas Ekonomi, Universitas Sanata Dharma, Indonesia
}

\begin{abstract}
Claim "go-green" continuously used in green marketing to emphasize the attributes of green product and with the aim of developing a green brand. The strength of a green brand reflects in its green brand equity. This study seeks to explore the relationship between green brand equity and its four proposed antecedents, namely the green brand image, green satisfaction, green trust and green brand perceived value. This research used a quantitative approach with self administered survey through an online and offline survey. Data were collected from 303 consumers of green cosmetics. The hypothesis was tested using multiple regression using SPSS 25. The results showed that green brand image, green satisfaction, green trust and green brand perceived value have a positive effect on green brand equity. Hence, investing in resources that increase these antecedents will enhance green brand equity.
\end{abstract}

Keywords: Green Brand Equity; Green Brand Image, Green Brand Perceived Value; Green Cosmetics; Green Satisfaction; Green Trust

\begin{abstract}
Abstrak
Pemasaran hijau menggunakan klaim "go-green" untuk menekankan atribut green product dan bertujuan membangun green brand. Kuatnya suatu merek hijau tercermin dari ekuitas merek hijau yang dimiliki. Penelitian ini bertujuan untuk menguji pengaruh anteseden ekuitas merek hijau yaitu citra merek hijau, kepuasaan hijau, kepercayaan hijau pada ekuitas merek hijau. Penelitian ini dilakukan dengan desain kuantatif. Teknik pengumpulan data dengan survei menggunakan self-administered survey dengan menyebarkan kuisoner secara daring dan luring. Data diperoleh dari 303 responden sebagai konsumen merek kosmetik hijau. Metode analisis data yang digunakan dalam penelitian ini menggunakan multiple regression dengan SPSS 25. Hasil penelitian menunjukkan bahwa citra merek hijau, kepuasaan hijau, kepercayaan hijau dan nilai merek hijau yang dipersepsikan berpengaruh positif dan signifikan pada ekuitas merek hijau. Investasi sumber daya dalam citra merek hijau, kepuasaan hijau, kepercayaan hijau akan meningkatkan ekuitas merek hijau.
\end{abstract}

Kata Kunci: Citra Merek Hijau; Ekuitas Merek Hijau; Kepercayaan Hijau; Kepuasaan Hijau; Kosmetik Hijau; Nilai Merek Hijau Yang Dipersepsikan

Article History: Received: (10.-08-2020); Revised: (16.-09-2020); and Published: (31-10-2020) Copyright C 2020 Maria Angela Diva

How to cite this article: Diva, M.A (2020). The Antecedents Green Brand Equity of Green Cosmetics. Managament Insight: Jurnal IImiah Manajemen. 15(2), 156-172.

Retrevied from: https://ejournal.unib.ac.id/index.php/Insight 


\section{PENDAHULUAN}

Kesadaran masyarakat akan isu-isu pelestarian lingkungan semakin meningkat dalam beberapa dekade terakhir. Kesadaran konsumen berasal dari pengetahuan mereka tentang pentingnya menciptakan lingkungan yang sehat dalam rangka meningkatkan kualitas hidup. Hal ini dapat dikendalikan oleh konsumen melalui perilakunya dengan merubah pilihan dan pola konsumsi produk yang ramah lingkungan (Yam-Tang \& Chan, 1998). Konsumen saat ini menunjukkan kepedulian yang lebih terhadap isu lingkungan dan sosial sehingga mulai merubah pola konsumsinya (Chen, 2010). Pola perubahan konsumsi konsumen menghadirkan "green generation"(Nielsen, 2015). Konsumen mengharapkan perusahaan untuk memperhatikan lingkungan dan sosial, Indonesia berada di peringkat empat dari enam negara tertinggi di Asia Tenggara terkait dengan kesediaan membayar lebih untuk produk dan jasa dari perusahaan yang berkomitmen terhadap dampak positif sosial dan lingkungan.

Nielsen (2015) melakukan survei terkait negara-negara yang memiliki kepedulian terhadap isu lingkungan dan perubahan iklim, dimana Indonesia termasuk dalam kategori negara yang sangat peduli terhadap isu lingkungan global. Peraturan Pemerintah Republik Indonesia Nomor 47 Tahun 2012 tentang Tanggung Jawab Sosial dan Lingkungan Perseroan Terbatas (2012:1) pada pasal dua, ditetapkan bahwa "[Setiap] perseroan selaku subjek hukum mempunyai tanggung jawab sosial dan lingkungan". Kebijakan pemerintah tersebut menjadi pedoman penggerak suatu industri di Indonesia untuk melaksanakan konsep ramah lingkungan (go-green) dalam setiap produksi, pemasaran, dan pelayanan demi tercapainya kepuasan pelanggan.

Kesadaran masyarakat akan masalah lingkungan semakin meningkat dengan munculnya berbagai isu lingkungan yang mempengaruhi kehidupan masyarakat baik secara langsung maupun tidak langsung. Isu lingkungan yang semakin menyeruak mengakibatkan gerakan hijau menyentuh segala lapisan industri, termasuk industri kosmetik. Kesadaran konsumen pada pentingnya kosmetik yang sehat serta tuntutan hidup yang lebih ramah lingkungan, lalu menyebabkan munculnya kosmetik hijau (green cosmetics) atau kosmetik ramah lingkungan (Rahayu, 2016). Industri kosmetik secara perlahan telah mengubah pola produksinya yang pada mulanya berorientasi bahan kimia menjadi bahan alami. Industri kosmetik yang berorientasi pada lingkungan menggunakan bahan-bahan alami, dan meminimalkan penggunaan senyawa kimia, teknik pengemasan yang lebih diperhatikan dengan menggunakan material seperti bambu atau bahan-bahan daur ulang untuk kemasannya. Kosmetik ramah lingkungan tidak hanya terbuat dari bahan-bahan alami, namun proses produksinya juga tidak memberikan dampak pada lingkungan (Rahayu,2016).

Menurut Euromonitor International (tahun 2015), negara-negara berkembang berkontribusi sebesar 51\% bagi industri kecantikan global, termasuk Indonesia. Indonesia memiliki pasar yang dinamis di kawasan Asia Tenggara. Indonesia merupakan salah satu pasar kosmetik yang besar sehingga industri kosmetik menjadi

Diva

157 | Ha I a man

The Antecedents Green Brand Equity of Green Cosmetics 
sangat prospektif dan menjanjikan. Performa industri kosmetik saat ini tumbuh secara positif di tengah pelemahan daya beli konsumen. Salah satu pendorongnya adalah perubahan gaya hidup konsumen yang kini telah memandang kosmetik sebagai kebutuhan primer dari sebelumnya tersier (Arief, 2019).

Industri kosmetik di Indonesia mengalami kenaikan pertumbuhan sebesar 20\% atau empat kali lipat dari pertumbuhan ekonomi nasional pada tahun 2017 (Kemenperin, 2018). Kenaikan pertumbuhan kosmetik didorong permintaan yang besar dari pasar dan tren masyarakat yang mulai memperhatikan produk perawatan tubuh sebagai kebutuhan utama. Kementerian Perindustrian menempatkan industri kosmetik sebagai sektor andalan sebagaimana tertuang dalam Rencana Induk Pembangunan Industri Nasional (RIPIN) tahun 2015-2035. Potensi pasar kosmetik di Indonesia dipengaruhi oleh meningkatnya jumlah penduduk usia muda atau generasi millennial dan tren masyarakat untuk menggunakan produk alami (back to nature).

Kesadaran konsumen akan hak-haknya untuk mendapatkan produk yang layak, aman dan ramah lingkungan yang semakin kuat, termasuk dalam hal kosmetik sehingga mendorong perusahaan untuk mulai menerapkan isu-isu lingkungan sebagai salah satu strategi pemasarannya atau yang telah dikenal sebagai pemasaran hijau. Pemasaran hijau dikenalkan secara terus menerus dengan tujuan untuk membangun suatu merek hijau. Merek hijau merupakan komunikator yang memberikan informasi tentang atribut merek yang unik suatu produk dan manfaat yang diberikan mengurangi dampak lingkungan, dan mewakili atribut produk ramah lingkungan (Huang, Yang, \& Wang, 2014). Kuatnya suatu merek tercermin dari ekuitas merek yang dimiliki. Dalam literatur pemasaran, terdapat berbagai konseptualisasi dari ekuitas merek seperti yang dikemukakan oleh (Chris A. Myers, 2003; Keller, 1993; Smith \& Aaker, 1992; Yoo \& Donthu, 2001). Berbagai konseptualiasi dari ekuitas merek yang ada dalam literatur pemasaran menunjukkan konsep dan perspektif yang berbeda-beda sehingga pengukuran yang digunakan dalam konseptualisasi ekuitas merek ini juga berbeda.

(Chen, 2010) mencoba mengeksplore dan memperkenalkan konstruk terkait ekuitas merek hijau yang dipengaruhi oleh citra merek hijau, kepuasaan hijau, dan kepercayaan hijau. Kemudian, bermunculan penelitian-penelitian terkait merek hijau dan ekuitas merek hijau dari berbagai perspektif (Bekk, Spörrle, Hedjasie, \& Kerschreiter, 2016; Buil, Martínez, \& de Chernatony, 2013; Huang et al., 2014; Kang \& Hur, 2012; Ng, Butt, Khong, \& Ong, 2014). Beberapa penelitian sebelumnya dari tinjauan beberapa literatur pemasaran hijau yang mengidentifikasi anteseden ekuitas merek hijau menemukan beberapa model dengan anteseden yang berbeda-beda. Beberapa model anteseden ekuitas merek hijau tersebut menggunakan beberapa konstruk yang sama, namun ada juga yang menggunakan beberapa konstruk yang berbeda (Bekk et al., 2016)

(Ng et al., 2014) menemukan bahwa kualitas merek, kredibilitas merek, citra merek hijau dan nilai merek hijau yang dipersepsikan memberikan pengaruh positif terhadap ekuitas merek hijau. Penelitian (Bekk et al., 2016) menegaskan kembali 
penelitian dari (Chen, 2010) dimana ekuitas merek hijau dipengaruhi oleh citra merek hijau, kepuasaan hijau dan kepercayaan hijau. (Delafrooz \& Goli, 2015) menegaskan kembali penelitian dari (Ng et al., 2014) dimana ekuitas merek hijau dipengaruhi oleh nilai merek hijau yang dipersepsikan dan citra merek hijau. Adanya perbedaan konstruk yang berbeda inilah sehingga menjadi lebih menarik untuk membandingkan beberapa model ekuitas merek hijau dalam rangka memeriksa variabel yang menjadi prediktor yang paling tepat dari ekuitas merek hijau (Bekk et al., 2016)

Penelitian ini bertujuan untuk menguji pengaruh anteseden ekuitas merek hijau yaitu citra merek hijau, kepuasaan hijau, kepercayaan hijau. Pengujian hipotesis penelitian ini menggunakan analisis regresi. Penjelasan hasil penelitian, implikasi penelitian, keterbatasan dan saran untuk penelitian selanjutnya dijelaskan kemudian.

\section{TINJAUAN PUSTAKAN DAN PENGEMBANGAN HIPOTESIS}

\section{Ekuitas Merek Hijau}

Merek yang kuat akan memiliki ekuitas merek yang tinggi. (Kotler \& Keller, 2016) mendefinisikan ekuitas merek sebagai nilai tambah yang diberikan pada barang dan jasa. (Kotler \& Keller, 2016) mengemukakan konsep ekuitas merek berbasis konsumen sebagai efek diferensial pengetahuan merek pada respon konsumen terhadap pemasaran dari sebuah merek. (Aaker, 1991) mendefinisikan ekuitas merek sebagai seperangkat aset dan kewajiban terkait dengan merek, nama dan simbol yang menambah atau mengurangi nilai yang diberikan oleh suatu produk atau jasa kepada perusahaan dan konsumen. Berdasarkan definisi di atas, ekuitas merek hijau didefinisikan sebagai seperangkat aset dan kewajiban/liabilitas yang dihubungkan dengan merek, nama dan simbol terkait dengan komitmennya akan kepedulian lingkungan yang menambah atau mengurangi nilai dari produk atau jasa (Chen, 2010)

\section{Anteseden Ekuitas Merek Hijau}

Beberapa penelitian terdahulu memaparkan beberapa model anteseden ekuitas merek hijau yang berbeda-beda (Bekk et al., 2016; Buil et al., 2013; Chen, 2010; Delafrooz \& Goli, 2015; Kang \& Hur, 2012; Konuk, Rahman, \& Salo, 2015; Ng et al., 2014). Chen (2010) memaparkan konsep ekuitas merek hijau dan antesedennya yang terdiri dari citra merek hijau, kepuasan hijau, dan kepercayaan hijau. Selanjutnya, ( $\mathrm{Ng}$ et al., 2014) mengemukakan anteseden ekuitas merek hijau yaitu kualitas merek, kredibilitas merek, citra merek hijau dan nilai merek hijau yang dipersepsikan. Anteseden ekuitas merek hijau yang digunakan dalam penelitian ini adalah citra merek hijau, kepuasaan hijau, kepercayaan hijau, dan nilai merek hijau yang dipersepsikan.

1. Citra Merek Hijau (Green Brand Image)

(Keller, 1993) mendeskripsikan citra merek sebagai seperangkat persepsi tentang sebuah merek yang direfleksikan oleh asosiasi merek tersebut dalam pikiran konsumen. Berdasarkan definisi tersebut citra merek hijau didefinisikan sebagai 
seperangkat persepsi tentang suatu merek dalam pikiran konsumen terkait dengan komitmen terhadap lingkungan dan masalah lingkungan (Chen, 2010). Komitmen terhadap lingkungan akan menghasilkan green competitive advantage, sehingga perusahaan berusaha untuk menciptakan citra hijau suatu merek (Chen \& Chang, 2012). Ketika perusahaan memahami pentingnya kampanye citra hijau maka akan meningkatkan ekuitas dari suatu merek dan mengarahkan perilaku konsumen (Ng et al., 2014)

2. Kepuasaan Hijau (Green Satisfaction)

Kepuasan adalah perasaan senang atau kecewa seseorang yang timbul dari hasil membandingkan kinerja produk yang dirasakan dengan apa yang diharapkan (Kotler \& Keller, 2016) Kepuasaan merupakan suatu tingkat keseluruhan rasa senang yang dirasakan konsumen dari suatu kualitas produk atau jasa dalam memenuhi harapan, keinginan dan kebutuhan konsumen (Mai dan Ness, 1999 dalam Chen, 2010). Kepuasan konsumen bergantung pada kinerja produk yang diterima yang dibandingkan dengan harapan konsumen. Berdasarkan definisi tersebut (Chen, 2010) mendefinisikan kepuasan hijau sebagai tingkat rasa yang dirasakan oleh konsumen sebagai hasil dari kualitas kinerja produk atau jasa dalam memenuhi ekspektasi, keinginan maupun kebutuhan konsumen terkait lingkungan.

3. Kepercayaan Hijau (Green Trust)

Kepercayaan bergantung pada kemampuan, kehandalan dan sesuatu hal yang baik. Aspek penting dalam kepercayaan adalah yakin (belief) atas reliabilitas, keamanan (safety) dan kejujuran (honesty) yang terkait dengan kemampuan untuk memenuhi kewajiban secara berkelanjutan. Kepercayaan merangkum pengetahuan konsumen dan pengalaman terhadap suatu merek (Kang \& Hur, 2012). Ganesan (1994) dalam (Chen, 2010) berpendapat bahwa kepercayaan adalah kemauan untuk tergantung pada pihak lain berdasarkan pada ekspektasi dari kemampuan, keandalan dan sikap baik dari pihak lain. Selanjutnya, kepercayaan hijau didefinisikan sebagai kesediaan untuk bergantung pada produk, jasa, atau merek berdasarkan ekspektasi akan kemampuan, keandalan dan sikap baik terhadap lingkungan (Chen, 2010).

4. Nilai Merek Hijau yang Dipersepsikan (Green Brand Perceived Value)

Nilai yang dipersepsikan merupakan bentuk evaluasi calon konsumen terhadap manfaat secara keseluruhan dan seluruh biaya yang ditawarkan serta alternatif yang diterima (Kotler \& Keller, 2016). Chen \& Chang (2012) mendefinisikan nilai hijau yang dipersepsikan sebagai penilaian konsumen secara keseluruhan terhadap merek dari produk atau jasa didasarkan pada apa yang mereka terima dan apa yang mereka berikan berdasarkan keinginan konsumen terhadap lingkungan, ekspektasi berkelanjutan dan kebutuhan hijau. Dalam konteks pemasaran hijau, atribut hijau dari suatu merek terintegrasi dengan nilai-nilai konvensional dalam rangka menghasilkan penerimaan oleh konsumen (Ng et al., 2014) 


\section{Pengaruh Citra Merek Hijau pada Ekuitas Merek Hijau}

Semakin baik suatu perusahaan menyampaikan fokusnya pada lingkungan di benak konsumen dapat meningkatkan citra hijau perusahaan/merek dengan sukses. (Konuk et al., 2015)Ketika perusahaan memahami pentingnya kampanye citra hijau maka akan meningkatkan ekuitas merek hijau (Bekk et al., 2016). Penelitian sebelumnya menunjukkan bahwa meningkatkan citra merek bermanfaat untuk meningkatkan ekuitas merek (Faircloth, Capella, \& Alford, 2001). Selain itu, Biel (1992) dalam (Huang et al., 2014) menyatakan bahwa ekuitas merek didorong oleh citra merek. Mourad \& Ahmed, (2012) mengemukakan bahwa kesadaran merek hijau dan citra merek hijau membangun ekuitas merek hijau. (Bekk et al., 2016) menemukan hasil citra merek hijau mempengaruhi ekuitas merek hijau secara langsung. ( $\mathrm{Ng}$ et al., 2014) menemukan citra merek hijau secara langsung mempengaruhi ekuitas merek hijau. Berdasarkan penjelasan di atas, dapat dirumuskan hipotesis :

H1: Citra merek hijau berpengaruh positif pada ekuitas merek hijau.

\section{Pengaruh Kepuasaan Hijau pada Ekuitas Merek Hijau}

Kepuasan mencerminkan tingkat konsumsi yang menyenangkan dan dapat memenuhi kebutuhan dan keinginan konsumen. Kepuasan hijau berkaitan dengan rasa yang dirasakan oleh konsumen yang bersifat menyenangkan sebagai hasil dari kualitas kinerja produk atau jasa dalam memenuhi ekspektasi, keinginan maupun kebutuhan konsumen terkait lingkungan (Chen, 2010). Kepuasaan terhadap suatu merek pada berdampak positif pada asosiasi yang kuat dan baik dalam pikiran konsumen sehingga membentuk hubungan positif antara kepuasaan konsumen terhadap suatu merek dan ekuitas merek (Pappu, Cooksey, \& Quester, 2005). Chen (2010) mengemukankan bahwa kepuasaan hijau berpengaruh positif pada ekuitas merek hijau. Selain itu, penelitian Bekk et al. (2016) menegaskan bahwa kepuasaan hijau secara langsung berpengaruh terhadap ekuitas merek hijau. Berdasarkan penjelasan di atas, dapat dirumuskan hipotesis sebagai berikut :

H2: Kepuasaan hijau berpengaruh positif terhadap ekuitas merek hijau.

\section{Pengaruh Kepercayaan Hijau pada Ekuitas Merek Hijau}

Literatur pemasaran menunjukkan bahwa kepercayaan adalah faktor utama suatu hubungan (Delgado-Ballester \& Munuera-Alemán, 2005). Ekuitas merek dianggap sebagai aset berbasis relational market dan melekat pada merek serta menanamkan hubungan dengan pelanggan (Srivastava dkk., 1998, dalam Chen, 2010). Keperecayaan merek merupakan hal penting karena akan meningkatkan ekuitas merek (Delgado-Ballester \& Munuera-Alemán, 2005). Penelitian sebelumnya menegaskan bahwa kepercayaan merek adalah penting untuk meningkatkan ekuitas merek dan kepercayaan merek dikaitkan secara positif dengan ekuitas merek (Delgado-Ballester \& Munuera-Alemán, 2005). Chen, (2010) menemukan bahwa kepercayaan merek hijau yang secara langsung memberikan pengaruh positif terhadap ekuitas merek hijau.

Diva

161 | H a I a m a n

The Antecedents Green Brand Equity of Green Cosmetics 
Kepercayaan merek hijau yang semakin meningkat akan meningkatkan ekuitas merek hijau (Bekk et al., 2016). Berdasarkan penjelasan di atas, dapat dirumuskan hipotesis berikut:

\section{H3: Kepercayaan hijau berpengaruh positif pada ekuitas merek hijau.}

\section{Pengaruh Nilai Merek Hijau yang Dipersepsikan pada Ekuitas Merek Hijau}

Membangun nilai merek yang dipersepsikan konsumen yang kuat dan positif merupakan hal yang penting karena memperkuat ekuitas merek berbasis konsumen (Malik, 2015). Nilai yang dipersepsikan memiliki pengaruh positif terhadap ekuitas merek (Jahanzeb, Fatima, \& Butt, 2013). Chen \& Chang (2012) mengemukakan bahwa niat konsumen membeli produk hijau akan meningkat jika nilai yang dirasakan dari produk dan merek hijau tersebut menguntungkan dan sesuai dengan apa yang diharapkan. Nilai merek hijau yang dipersepsikan yang sesuai akan membentuk ekuitas merek hijau pada konsumennya (Delafrooz \& Goli, 2015). Chen \& Chang (2012)mengemukakan bahwa nilai merek hijau yang dipersepsikan dapat "digenerate" secara substansial terhadap ekuitas merek hijau (Ottman, 2007). Ng et al. (2014) menemukan bahwa nilai hijau yang dipersepsikan berhubungan secara langsung terhadap ekuitas merek hijau Berdasarkan penjelasan di atas, dapat dirumuskan hipotesis sebagai berikut :

H4: Nilai merek hijau yang dipersepsikan berpengaruh positif pada ekuitas merek hijau

Model penelitian ini menggambarkan kerangka model citra merek hijau, kepuasaan hijau, kepercayaan hijau dan nilai hijau dalam membangun ekuitas merek hijau. Anteseden ekuitas merek hijau yang digunakan dalam penelitian ini adalah citra merek hijau (Bekk et al., 2016; Chen, 2010; Ng et al., 2014); kepuasaan hijau (Bekk et al., 2016; Chen, 2010; Kang \& Hur, 2012); kepercayaan hijau (Bekk et al., 2016; Chen, 2010); dan nilai merek hijau hijau (Ng et al., 2014).

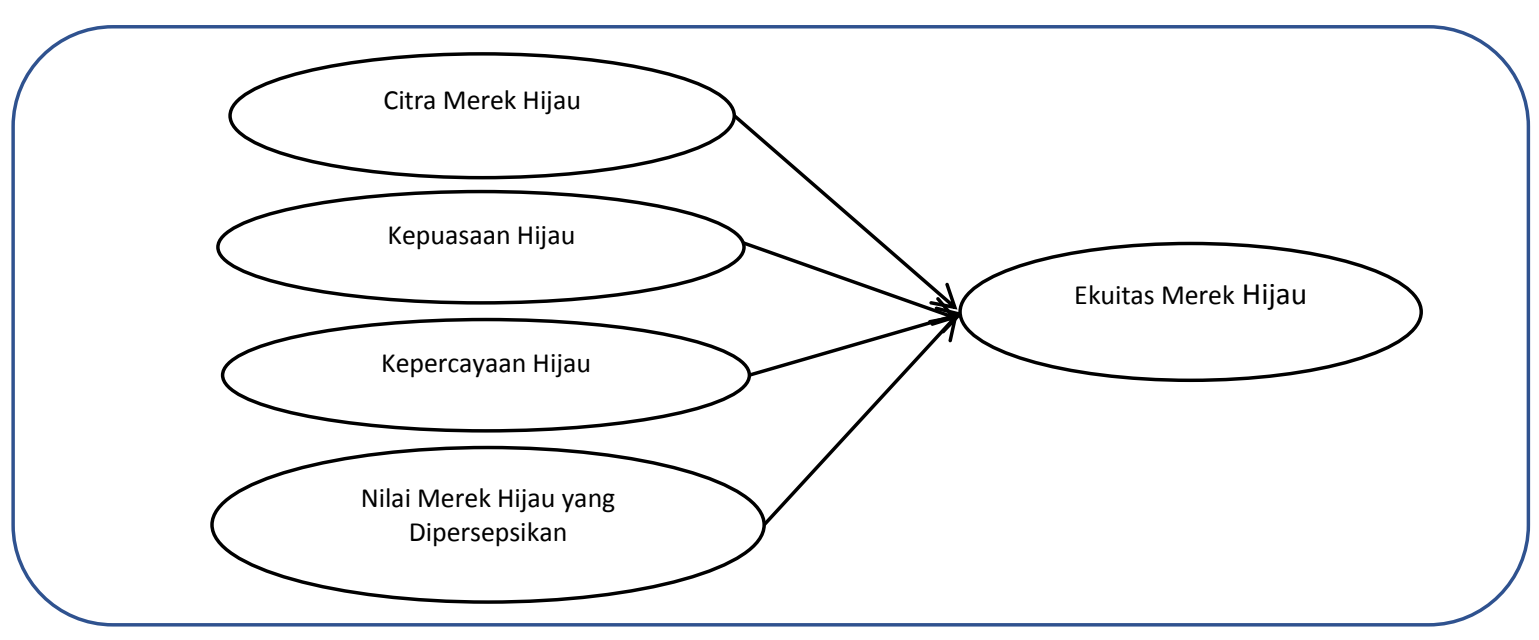

Gambar 1. Kerangka Penelitian

Sumber : Diolah dan diadopsi dari Chen (2010) dan Ng dkk. (2014)

Diva

162 | Ha I a ma n

The Antecedents Green Brand Equity of Green Cosmetics 


\section{METODE PENELITIAN}

Penelitian ini termasuk penelitian kuantitatif, bersifat konfirmatori dan cross sectional. Responden dalam penelitian ini dipilih dengan menggunakan teknik purposive sampling. Kriteria responden dalam penelitian ini adalah orang yang mengetahui dan menggunakan merek kosmetik hijau dalam tiga bulan terakhir. Merek kosmetik hijau yang digunakan responden dalam penelitian ini merupakan merek kosmetik hijau yang paling sering digunakan responden.

Pengumpulan data dalam penelitian ini menggunakan metode survey dengan menyebarkan kuesioner kepada responden melalui luring dan daring. Total kuesioner yang dapat digunakan untuk dianalisis dalam penelitian ini adalah sebanyak 303 kuesioner. Kuesioner yang dapat dianalisis melalui luring sebanyak 136 kuesioner $(44,8 \%)$ dan kuesioner yang dapat dianalisis melalui daring sebanyak 167 kuesioner $(55,2 \%)$, sehingga total kuesioner yang dapat digunakan sebanyak 303 kuesioner (100\%). Data yang terkumpul dalam penelitian ini diuji dengan menggunakan independent sample $T$ test. Pengujian ini digunakan untuk mengetahui ada atau tidaknya perbedaan antara dua kelompok sampel (Hair dkk., 2010: 459).

Hasil uji beda antara kuesioner luring dan daring menunjukkan bahwa nilai signifikansi uji beda setiap variabel pada penelitian ini baik yang disebarkan secara luring dan daring berada di atas 0,05. Artinya, tidak ada perbedaan yang signifikan antara rata-rata jawaban kuesioner yang disebarkan melalui daring dan luring sehingga kuesioner luring dan daring dapat digabungkan untuk dianalisis lebih lanjut.

\section{ANALISIS DATA}

\section{Karakteristik Responden}

Pada penelitian ini meskipun meneliti tentang merek kosmetik hijau, namun tidak membatasi pada jenis kelamin. Perubahan pola konsumsi masyarakat mendorong adanya kebutuhan kosmetik untuk pria seperti menjaga penampilan dan wajah. Responden dalam penelitian ini sebagian besar adalah perempuan yaitu sebanyak 294 orang $(97 \%)$ dan responden laki-laki berjumlah 9 orang (3\%). Hal ini menunjukkan bahwa produk kosmetik hijau didominasi oleh konsumen perempuan khususnya di Indonesia.

Responden yang menggunakan merek kosmetik hijau dalam penelitian ini sebagian besar berusia 21 tahun - 30 tahun yaitu sebanyak 192 (63,4\%), hal ini dikarenakan rentan usia tersebut konsumen sangat memperhatikan produk-produk kosmetik untuk perawatan tubuh dan menunjang kecantikan. Responden dengan usia 31 tahun - 40 tahun sebanyak 18,2\%, berusia 41 tahun - 50 tahun sebanyak 10,6\% dan responden yang berusia $>50$ tahun sebanyak 5,3\%. Yang terakhir adalah responden yang berusia $<20$ tahun hanya $2,6 \%$. 
Tabel 1. Merek Kosmetik Hijau

\begin{tabular}{lcc}
\hline \multicolumn{1}{c}{ Merek } & Frekuensi & Presentase \\
\hline The Body Shop & 180 & $59,4 \%$ \\
The Face Shop & 24 & $7,9 \%$ \\
Oriflame & 78 & $25,7 \%$ \\
L' Oreal & 15 & $5,0 \%$ \\
\hline Lainnya & 6 & $2,0 \%$
\end{tabular}

Sumber : Data primer yang diolah (2020)

Merek kosmetik hijau yang paling banyak digunakan responden dalam penelitian ini adalah The Body Shop sebanyak 59,4\%. Oriflame menduduki urutan kedua dari merek kosmetik hijau yang digunakan responden dalam penelitian ini yaitu sebanyak $25,7 \%$. Selanjutnya, responden yang menggunakan merek kosmetik hijau The Face Shop sebanyak 7,9\% dan L'oreal 5\%. Beberapa responden juga menggunakan merek kosmetik hijau yang lainnya yaitu Larissa sebanyak $1 \%$ dan L'Occitane sebanyak $1 \%$.

Responden dengan pendidikan S1 mendominasi total responden dalam penelitian ini yaitu berjumlah 167 orang $(55,1 \%)$. Kemudian responden dengan jenjang pendidikan S2 23,4\%, jenjang pendidikan Diploma (D3) sebanyak 13,9\%, jenjang pendidikan SMA 5,3\% dan responden dengan pendidikan SMP 2\%. Yang terakhir terdapat satu responden (0,3\%) dengan tingkat pendidikan Doktor (S3).

Responden dengan tingkat pendapatan/bulan sebesar Rp 1.000 .000 - Rp 4.999.999 memiliki presentase terbesar yaitu sebesar $56,4 \%$ dari total responden. Responden dengan tingkat pendapatan/bulan sebesar Rp 5.000.000 - Rp 9.999.999 $25,7 \%$ dan responden dengan tingkat pendapatan per bulan sebesar $>$ Rp 10.000.000 sebanyak $12,5 \%$. Yang terakhir, responden dalam penelitian ini yang memiliki tingkat pendapatan per bulan < Rp 999.999 sebesar 5,3\%.

Mourad (2012) menunjukkan temuan bahwa faktor-faktor yang mempengaruhi ekuitas merek secara signifikan berbeda dalam tingkat pendapatan dan pendidikan yang berbeda pula. Penelitian sebelumnya menunjukkan bahwa demografis konsumen berpengaruh terhadap environmental behavior. Henion (1972) dalam Mourad (20120) menemukan bahwa konsumen yang tingkat pendidikannya lebih tinggi dan penghasilannya lebih besar memiliki environmental behavior yang lebih baik terhadap lingkungannya. Hal ini menunjukkan bahwa konsumen hijau tidak terlepas kaitannya dengan tingkat pendidikan dan penghasilan.

\section{Hasil Pengujian Instrumen Uji Validitas}

Penguijan validitas digunakan untuk mengukur seberapa akuratnya pengukuran dalam mengukur apa yang seharusnya diukur atau sejauh mana tingkat akurasi dapat merepresentasikan sebuah indikator dalam menilai sesuatu (Cooper \& Schindler, 2014; Hair, Jr, 2015) Pengujian validitas dilakukan pada kelima variabel yaitu citra merek 
hijau, kepuasan hijau, kepercayaan hijau, nilai merek hijau yang dipersepsikan dan ekuitas merek hijau. Tabel 2 menyajikan hasil pengujian validitas citra merek hijau.

Tabel 2. Hasil Uji Validitas Citra Merek Hijau

\begin{tabular}{ccccc}
\hline NO ITEM & R hitung & Sig & N & KETERANGAN \\
\hline CMH1 & 0,873 & 0,000 & 303 & Valid \\
CMH2 & 0,901 & 0,000 & 303 & Valid \\
CMH3 & 0,884 & 0,000 & 303 & Valid \\
CMH4 & 0,885 & 0,000 & 303 & Valid \\
CMH5 & 0,496 & 0,000 & 303 & Valid \\
\hline
\end{tabular}

Sumber data : data primer yang diolah (2020)

Tabel 3 menunjukkan bahwa semua item pernyataan variabel citra merek hijau valid. Semua item pernyataan menunjukkan angka $r_{\text {hitung }}$ yang lebih besar dari pada $r_{\text {tabel, }}$ yaitu 0,095. Selanjutnya, Tabel 3 menyajikan hasil pengujian validitas kepuasaan hijau.

Tabel 3. Hasil Uji Validitas Kepuasaan Hijau

\begin{tabular}{ccccc}
\hline NO ITEM & R hitung & Sig & N & KETERANGAN \\
\hline KP1 & 0,833 & 0,000 & 303 & Valid \\
KP2 & 0,876 & 0,000 & 303 & Valid \\
KP3 & 0,856 & 0,000 & 303 & Valid \\
KP4 & 0,836 & 0,000 & 303 & Valid \\
\hline Sumber data
\end{tabular}

Sumber data : data primer yang diolah (2020)

Berdasarkan hasil pengujian validitas kepuasaan hijau pada Tabel 4 terdapat empat item pernyataan yang dinyatakan valid karena angka $r_{\text {hitung }}$ yang lebih besar dari pada

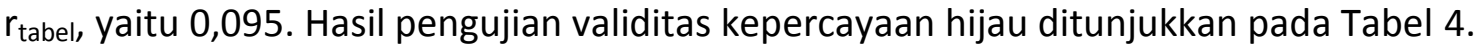

Tabel 4. Hasil Uji Validitas Kepercayaan Hijau

\begin{tabular}{ccccc}
\hline NO ITEM & R hitung & Sig & N & KETERANGAN \\
\hline KH1 & 0,828 & 0,000 & 303 & Valid \\
KH2 & 0,842 & 0,000 & 303 & Valid \\
KH3 & 0,839 & 0,000 & 303 & Valid \\
KH4 & 0,869 & 0,000 & 303 & Valid \\
KH5 & 0,821 & 0,000 & 303 & Valid \\
\hline
\end{tabular}

Sumber data : data primer yang diolah (2020)

Tabel 4 menunjukkan bahwa semua item pernyataan variabel kepuasan hijau valid. Semua item pernyataan menunjukkan angka $r_{\text {hitung }}$ yang lebih besar dari pada $r_{\text {tabel, }}$ yaitu 0,095. Tabel 5 menyajikan hasil pengujian validitas nilai merek hijau yang dipersepsikan. 
Tabel 5. Hasil Uji Validitas Nilai Merek Hijau yang Dipersepsikan

\begin{tabular}{ccccc}
\hline NO ITEM & R hitung & Sig & N & KETERANGAN \\
\hline NHP1 & 0,835 & 0,000 & 303 & Valid \\
NHP2 & 0,877 & 0,000 & 303 & Valid \\
NHP3 & 0,884 & 0,000 & 303 & Valid \\
NHP4 & 0,856 & 0,000 & 303 & Valid \\
\hline Sumber data : data primer yang diolah (2020)
\end{tabular}

Berdasarkan hasil pengujian validitas nilai merek hijau yang dipersepsikan pada Tabel 5 terdapat empat item pernyataan yang dinyatakan valid karena angka $r_{\text {hitung }}$ yang lebih

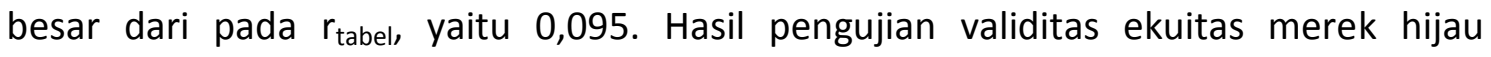
ditunjukkan pada Tabel 6.

Tabel 6. Hasil Uji Validitas Ekuitas Merek Hijau

\begin{tabular}{ccccc}
\hline NO ITEM & R hitung & Sig & N & KETERANGAN \\
\hline EMH1 & 0,733 & 0,000 & 303 & Valid \\
EMH2 & 0,797 & 0,000 & 303 & Valid \\
EMH3 & 0,828 & 0,000 & 303 & Valid \\
EMH4 & 0,848 & 0,000 & 303 & Valid \\
\hline
\end{tabular}

Sumber data : data primer yang diolah (2020)

Tabel 6 menyajikan semua item pernyataan variabel ekuitas merek hijau valid, hal ini ditunjukkan melalui masing-masing angka $r_{\text {hitung }}$ yang lebih besar dari pada $r_{\text {tabel, }}$ yaitu 0,095 . Berdasarkan pengujian validitas semua variabel menunjukkan bahwa seluruh item pernyataan ( 28 item pernyataan) dinyatakan valid.

\section{Uji Reliabilitas}

Reliabilitas berhubungan dengan akurasi dan ketepatan dari prosedur pengukuran dengan melihat konsistensi internal indikator-indikator sebuah konstruk dalam menilai sesuatu (Cooper \& Schindler, 2014) Kriteria nilai reliabilitas yang baik adalah nilai cronbach's alpha lebih besar dari 0,7 (Hair, Jr, 2015). Hasil uji reliabilitas yang ditampilkan pada Tabel 8 menunjukkan bahwa konstruk yang diukur adalah reliabel, karena semua variabel memiliki nilai cronbach's alpha di atas 0,7. Tabel 7 menyajikan hasil uji reliabilitas.

Tabel 7. Hasil Pengujian Reliabilitas

\begin{tabular}{lcc}
\hline Variabel & Cronbach's Alpha & Keterangan \\
\hline Citra Merek Hijau & 0,883 & Reliabel \\
Kepuasaan Hijau & 0,872 & Reliabel \\
Kepercayaan Hijau & 0,894 & Reliabel \\
Nilai Merek Hijau yang Dipersepsikan & 0,886 & Reliabel \\
Ekuitas Merek Hijau & 0,815 & Reliabel \\
\hline Sumber data : data primer yang diolah (2020)
\end{tabular}




\section{HASIL PENELITIAN}

\section{Hasil Uji Hipotesis}

Penelitian ini menggunakan analisis regresi dengan menggunakan SPSS 25. Uji kelayakan model dilakukan untuk melihat apakah model yang dianalisis memiliki kelayakan dimana variabel-varibel yang digunakan dalam model mampu menjelaskan fenomena yang dianalisis (Ferdinand, 2011). Uji kelayakan model dalam penelitian ini dilihat dari uji F. Tabel 8 dan 9 menunjukkan hasil Uji F sebagai berikut :

Tabel 8. Model Summary ${ }^{\mathrm{b}}$

\begin{tabular}{lrrr}
\hline Model & $\mathrm{R}$ & R Square & Adjusted R Square \\
\hline 1 & $.604^{\mathrm{a}}$ & .364 & .356 \\
\hline
\end{tabular}

Sumber data : data primer yang diolah (2020)

Tabel 9. ANOVAa

\begin{tabular}{llrrrrrr}
\hline \multirow{2}{*}{ Model } & Sum of & & & & \\
& & Squares & df & Mean Square & \multicolumn{1}{l}{ F } & \multicolumn{1}{c}{ Sig. } \\
\hline 1 & Regression & 43.927 & 4 & 10.982 & 42.708 & $.000^{b}$ \\
& Residual & 76.626 & 298 & .257 & & \\
& Total & 120.554 & 302 & & & \\
\hline
\end{tabular}

Sumber data : data primer yang diolah (2020)

Tabel 8. menunjukkan nilai $R^{2}$ sebesar 0,364 yang berarti ekuitas merek hijau dipengaruhi oleh citra merek hijau, kepuasaan hijau, kepercayaan hijau dan nilai merek hijau yang dipersepsikan sebesar 36,4\% sedangkan sisanya, 63,6\% dipengaruhi oleh variabel lain yang tidak dibahas dalam penelitian ini. Tabel 9 menunjukkan bahwa nilai $F$ hitung sebesar 42,408 yang berarti $F_{\text {hitung }}>F_{\text {tabel }}$, dimana nilai $F_{\text {tabel }}$ sebesar 2,20 dan nilai siginifikansi dibawah 0,05 yaitu 0,00. Hal ini dapat diartikan bahwa citra merek hijau, kepuasaa hijau, kepercayaan hijau dan nilai merek hijau yang dipersepsikan secara bersama-sama mempengaruhi ekuitas merek hijau.

Tabel 10. Hasil Pengujian Hipotesis

\begin{tabular}{cc|c|c|c|c}
\hline \multicolumn{2}{c}{ Model } & Unstandardized Coefficients & Standardized Coefficients & t & Sig. \\
\hline 1 & B & Std. Error & Beta & \\
\hline (Constant) & .914 & .231 & & 3.952 & .000 \\
\hline ACMH & .183 & .060 & .195 & 3.027 & .003 \\
\hline AKP & .145 & .066 & .142 & 2.206 & .028 \\
\hline AKH & .175 & .075 & .155 & 2.332 & .020 \\
\hline ANPH & .235 & .068 & .232 & 3.461 & .001 \\
\hline
\end{tabular}

Sumber data : data primer yang diolah (2020)

Hipotesis diterima apabila nilai dari thitung lebih besari dari $t_{\text {tabel. Hasil }}$ pengujian hipotesis dari penelitian ini dapat dilihat pada Tabel 10. Berdasarkan Tabel 10. menunjukkan bahwa citra merek hijau, kepuasaan hijau, kepercayaan hijau dan nilai merek hijau yang dipersespsikan memiliki memiliki $T_{\text {hitung }}>T_{\text {tabel }}$ dengan nilai signifikansi $p<0,05$. Citra merek hijau memiliki $T_{\text {hitung }}>T_{\text {tabel }}$ dengan nilai 3.027>1,959 
dengan nilai signifikansi $p<0,05$ yaitu 0,03 . Hal ini menunjukkan bahwa $\mathrm{H} 1$ diterima, citra merek hijau berpengaruh positif terhadap ekuitas merek hijau. Kepuasaan hijau memiliki $T_{\text {hitung }}>T_{\text {tabel }}$ dengan nilai 2,206>1,959 dengan nilai signifikansi $p<0,05$ yaitu 0,028 . Hal ini menunjukkan bahwa $\mathrm{H} 2$ diterima, kepuasaan hijau berpengaruh positif terhadap ekuitas merek hijau. Kepercayaan hijau memiliki $T_{\text {hitung }}>T_{\text {tabel }}$ dengan nilai $2,332>1,959$ dengan nilai signifikansi $p<0,05$ yaitu 0,020 . Hal ini menunjukkan bahwa H3 diterima, kepercayaan hijau berpengaruh positif terhadap ekuitas merek hijau. Nilai merek hijau yang dipersepsikan memiliki $T_{\text {hitung }}>T_{\text {tabel }}$ dengan nilai 3,461 $>1,959$ dengan nilai signifikansi $p<0,05$ yaitu 0,001 . Hal ini menunjukkan bahwa $\mathrm{H} 4$ diterima, nilai merek hijau yang dipersepsikan berpengaruh positif terhadap ekuitas merek hijau. Pembahasan lebih komprehensif terkait hasil pengujian hipotesis dan temuan dalam penelitian ini akan dibahas lebih lanjut.

\section{Pembahasan}

Hasil penelitian menunjukkan bahwa citra merek hijau berpengaruh positif dan signifikan pada ekuitas merek hijau dengan $T_{\text {hitung }}>T_{\text {tabel }}$ dengan nilai 3,027>1,959 dengan nilai signifikansi $p<0,05$ yaitu 0,03 . ). Hasil penelitian ini sesuai dengan penelitian yang dilakukan Bekk et al., (2016); Chen (2010). Citra merek merupakan kontributor utama pada ekuitas merek dan memiliki pengaruh yang positif dan signifikan (Chang \& Liu, 2009) Citra merek hijau merupakan hal penting yang harus diperhatikan perusahaan dalam membangun suatu merek khususnya merek hijau karena berkaitan dengan konsumen yang peduli terhadap lingkungannya dan environmental protection (Delafrooz \& Goli, 2015). Komitmen terhadap lingkungan akan menghasilkan keunggulan kompetitif hijau (green competitive advantage), sehingga perusahaan berusaha untuk menciptakan citra merek hijau dari suatu produk yang merek tawarkan kepada konsumen (Chen \& Chang, 2012). Ketika perusahaan memahami pentingnya kampanye citra hijau maka akan meningkatkan ekuitas merek (Bekk et al., 2016) Semakin baik suatu perusahaan menyampaikan fokusnya terkait dengan lingkungan pada benak konsumen maka akan meningkatkan citra merek hijau dari perusahaan tersebut (Konuk et al., 2015) sehingga dapat berdampak pada ekuitas merek hijau. Konsumen kosmetik di Indonesia yang memiliki citra merek hijau yang baik akan membangun ekuitas merek hijau dari produk kosmetik hijau.

Hasil penelitian menunjukkan bahwa kepuasaan hijau berpengaruh positif dan signifikan pada ekuitas merek hijau dengan $T_{\text {hitung }}>T_{\text {tabel }}$ dengan nilai 2,206>1,959 dengan nilai signifikansi $p<0,05$ yaitu 0,028 . Hal ini menjelaskan bahwa tingkat kepuasaan hijau konsumen yang menggunakan merek kosmetik hijau mempunyai pengaruh signifikan pada ekuitas merek hijau. Hasil penelitan yang dilakukan Bekk et al. (2016) dan Konuk et al. (2015) menguatkan hasil penelitian ini. Kepuasan hijau merupakan suatu hal yang dirasakan oleh konsumen sebagai hasil dari kualitas kinerja produk atau jasa dalam memenuhi ekspektasi, keinginan maupun kebutuhan 
konsumen terkait dengan dampak yang ditimbulkan pada lingkungan.Konsumen kosmetik di Indonesia yang memiliki tingkat kepuasaan hijau yang tinggi akan membangun ekuitas merek hijau dari produk kosmetik hijau. Semakin tinggi kepuasaan hijau dari konsumen yang menggunakan merek kosmetik hijau maka ekuitas merek hijau pada konsumen tersebut akan semakin baik.

Selanjutnya, hasil penelitian menunjukkan bahwa kepercayaan hijau berpengaruh positif dan signifikan pada ekuitas merek hijau dengan $T_{\text {hitung }}>T_{\text {tabel }}$ dengan nilai 2,332>1,959 dengan nilai signifikansi $p<0,05$ yaitu 0,020 . Hasil penelitan yang dilakukan Bekk et al. (2016); Chen (2010); Konuk et al. (2015), menguatkan hasil penelitian ini. Kepercayaan konsumen merupakan penentu yang signifikan dari ekuitas merek (Ambler, 1997 dalam Chen, 2010). Kepercayaan merek merupakan hal yang penting untuk meningkatkan ekuitas merek dan kepercayaan merek dikaitkan secara positif dengan ekuitas merek (Delgado-Ballester \& Munuera-Alemán, 2005). Konsumen kosmetik di Indonesia yang memiliki tingkat kepercayaan hijau dapat membangun ekuitas merek hijau dari produk kosmetik hijau. Semakin tinggi kepercayaan hijau konsumen akan merek kosmetik hijau yang merek gunakan maka ekuitas merek hijau konsumen tersebut akan semakin baik.

Hasil penelitian menunjukkan bahwa nilai merek hijau yang dipersepsikan berpengaruh positif dan signifikan pada ekuitas merek hijau dengan $T_{\text {hitung }}>T_{\text {tabel }}$ dengan nilai 3,461>1,959 dengan nilai signifikansi $p<0,05$ yaitu 0,001 . Penelitian ini mengkonfirmasi penelitian Ng et al. (2014) dan Delafrooz \& Goli (2015). Lassar, Mittal, \& Sharma (1995) mengemukakan bahwa merek memiliki ekuitas lebih tinggi karena nilai merek yang dipersepsikan. Ketika perusahaan membangun ekuitas merek maka salah satu hal penting yang harus diperhatikan adalah bagaimana membangun nilai merek yang dipersepsikan oleh konsumen (Malik, 2015). Ekuitas merek merupakan hasil dari evaluasi subjektif dari nilai merek yang dipersepsikan (Baldauf, Cravens, \& Binder, 2003), semakin baik dan positif nilai merek hijau yang dipersepsikan maka ekuitas merek hijau yang dimiliki konsumennya akan semakin meningkat. Semakin baik nilai merek hijau yang persepsikan konsumen yang menggunakan merek kosmetik hijau maka ekuitas merek hijau pada konsumennya akan semakin tinggi.

\section{KESIMPULAN DAN KETERBATASAN}

Kesadaran masyarakat terhadap lingkungan semakin meningkat dengan munculnya berbagai isu lingkungan yang mempengaruhi kehidupan masyarakat. Kesadaran konsumen akan pentingnya kosmetik yang sehat serta tuntutan hidup yang lebih ramah lingkungan, menghadirkan kosmetik hijau (green cosmetics). Hasil penelitian ini menunjukkan bahwa dalam konteks pemasaran hijau, ekuitas merek hijau dipengaruhi oleh citra merek hijau, kepuasaan hijau, kepercayaan hijau dan nilai hijau yang dipersepsikan. Merek hijau yang memiliki citra merek hijau yang semakin baik, kepuasaan hijau dari konsumen yang semakin tinggi, kepercayaan hijau konsumennya yang semakin meningkat dan nilai merek hijau yang dipersepsikan 
konsumen yang semakin sesuai maka akan menciptakan ekuitas merek hijau yang semakin tinggi.

Citra merek hijau yang tertanam dalam benak konsumen diharapkan akan memperoleh kepercayaan hijau, kepuasaan hijau dan nilai merek hijau yang dipersespsikan yang sesuai sehingga akan meningkatkan ekuitas merek hijau. Penelitian ini juga dapat dijadikan sebagai bahan masukan dalam merumuskan strategi pemasaran dan pengambilan keputusan serta kebijakan terkait dengan manajemen merek khusunya merek hijau. Selain itu, dapat memberikan gambaran bagi para pemasar dalam menyusun strategi untuk memasarkan produk kosmetik hijau secara efektif dan efisien.

Ekuitas merek hijau masih menjadi perdebatan dalam hal anteseden sehingga menimbulkan perbedaan beberapa konstruk yang membentuk anteseden ekuitas merek hijau. Penelitian di masa mendatang disarankan untuk menggunakan anteseden ekuitas merek hijau berbeda sehingga dapat membandingkan model ekuitas merek hijau. Penelitian ini hanya fokus pada satu produk kategori saja yaitu kosmetik hijau, penelitian selanjutnya disarankan untuk memperluas objek penelitian dengan beberapa produk katogeri yang terkait dengan produk hijau atau industri elektronik dan otomotif.

\section{DAFTAR PUSTAKA}

Aaker, D. a. (1991). Managing Brand Equity. Journal of Marketing.

Arief, A.M (2019), Industri Kosmetik tetap Tumbuh Cantik. Diakses dari https://ekonomi.bisnis.com/read/20191018/257/1160664/industri-kosmetikatetap-tumbuh-cantik, diakses tanggal 27 februari 2020

Baldauf, A., Cravens, K. S., \& Binder, G. (2003). Performance consequences of brand equity management: Evidence from organizations in the value chain. Journal of Product \& Brand Management.

Bekk, M., Spörrle, M., Hedjasie, R., \& Kerschreiter, R. (2016). Greening the competitive advantage: antecedents and consequences of green brand equity. Quality and Quantity.

Buil, I., Martínez, E., \& de Chernatony, L. (2013). The influence of brand equity on consumer responses. Journal of Consumer Marketing.

Chang, H. H., \& Liu, Y. M. (2009). The impact of brand equity on brand preference and purchase intentions in the service industries. Service Industries Journal.

Chen, Y. S. (2010). The drivers of green brand equity: Green brand image, green satisfaction, and green trust. Journal of Business Ethics.

Chen, Y. S., \& Chang, C. H. (2012). Enhance green purchase intentions: The roles of green perceived value, green perceived risk, and green trust. Management Decision.

Chris A. Myers. (2003). Managing brand equity: a look at the impact of attributes. 
Journal of Product \& Brand Management .

Cooper, D. R., \& Schindler, P. S. (2014). Business Research Methods 12th Edition. Business Research Methods.

Delafrooz, N., \& Goli, A. (2015). The factors affecting the green brand equity of electronic products: Green marketing. Cogent Business and Management.

Delgado-Ballester, E., \& Munuera-Alemán, J. L. (2005). Does brand trust matter to brand equity? Journal of Product and Brand Management.

Faircloth, J. B., Capella, L. M., \& Alford, B. L. (2001). The Effect of Brand Attitude and Brand Image on Brand Equity. Journal of Marketing Theory and Practice.

Ferdinand, A. (2011). Metode Penelitian Manajemen Pedoman Penelitian untuk Penulisan Skripsi Tesis dan disertai Ilmu Manajemen. Semarang: Universitas Diponegoro.

Hair, Jr, J. F. (2015). Essentials of Business Research Methods. Essentials of Business Research Methods.

Huang, Y. C., Yang, M., \& Wang, Y. C. (2014). Effects of green brand on green purchase intention. Marketing Intelligence and Planning.

Jahanzeb, S., Fatima, T., \& Butt, M. M. (2013). How service quality influences brand equity: The dual mediating role of perceived value and corporate credibility. International Journal of Bank Marketing.

Kang, S., \& Hur, W. M. (2012). Investigating the Antecedents of Green Brand Equity: A Sustainable Development Perspective. Corporate Social Responsibility and Environmental Management.

Keller, K. L. (1993). Conceptualizing, Measuring, and Managing Customer-Based Brand Equity. Journal of Marketing.

Kementerian Perindustrian (2018), Industri Kosmetik Nasional Tumbuh 20\%. Diakses dari https://kemenperin.go.id/artikel/18957/Industri-Kosmetik-NasionalTumbuh-20, diakses tanggal 20 februari 2020

Konuk, F. A., Rahman, S. U., \& Salo, J. (2015). Antecedents of green behavioral intentions: A cross-country study of Turkey, Finland and Pakistan. International Journal of Consumer Studies.

Kotler, P., \& Keller, K. L. (2016). Marketing Management 15/e. Prentice Hall.

Lassar, W., Mittal, B., \& Sharma, A. (1995). Measuring customer-based brand equity. Journal of Consumer Marketing.

Malik, M. (2015). Value-Enhancing Capabilities of CSR: A Brief Review of Contemporary Literature. Journal of Business Ethics.

Mourad, M., \& Ahmed, Y. S. E. (2012). Perception of green brand in an emerging innovative market. European Journal of Innovation Management.

Ng, P. F., Butt, M. M., Khong, K. W., \& Ong, F. S. (2014). Antecedents of Green Brand Equity: An Integrated Approach. Journal of Business Ethics.

Nielsen. (2015). Green Generation: Millennials say sustainability is a shopping priority. The Nielsen Global Survey of Corporate Social Responsibility and Sustainability. 
Nielsen N.V (2015), Sustainability Terus Memiliki Momentum Tersendiri Bagi Konsumen Asia Tenggara. Diakses dari http://www.nielsen.com/id/en/pressroom/2015/SUSTAINABILITY-TERUS-MEMILIKI-MOMENTUM-TERSENDIRI-BAGIKONSUMEN-ASIA-TENGGARA.html, diakses tanggal 20 februari 2020

Okezone (2012), Kosmetik "Hijau" Bukan Mimpi. Diakses dari http://lifestyle.okezone.com/read/2012/03/12/28/591564/kosmetik-hijaubukan-mimpi, diakses tanggal 27 februari 2020

Ottman, J. A. (2007). Green Marketing: Challenges and Opportunities for the New Marketing Age. Journal of the Academy of Marketing Science.

Pappu, R., Cooksey, R. W., \& Quester, P. G. (2005). Consumer-based brand equity: improving the measurement - empirical evidence. Journal of Product \& Brand Management.

Smith, D. C., \& Aaker, D. A. (1992). Managing Brand Equity: Capitalizing on the Value of a Brand Name. Journal of Marketing.

Yam-Tang, E. P. Y., \& Chan, R. Y. k. (1998). Purchasing behaviours and perceptions of environmentally harmful products. Marketing Intelligence \& Planning.

Yoo, B., \& Donthu, N. (2001). Developing and validating a multidimensional consumerbased brand equity scale. Journal of Business Research. 